\title{
Impact of long-term fertilization practices on the abundance and composition of soil bacterial communities in Northeast China
}

\author{
Ju-Pei Shen ${ }^{\text {a }}$, Li-Mei Zhang a , Jun-Fu Guo ${ }^{\text {a }}$, Jessica L. Ray ${ }^{\mathrm{b}}$, Ji-Zheng He ${ }^{\mathrm{a}, *}$

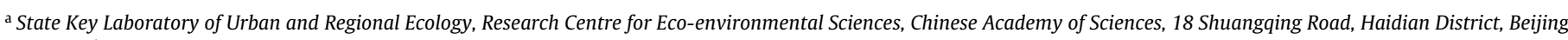 \\ 100085, China \\ ${ }^{\mathrm{b}}$ Department of Biology, University of Bergen, PO Box 7800, N-5020 Bergen, Norway
}

\section{A R T I C L E I N F O}

\section{Article history:}

Received 17 November 2009

Received in revised form 6 April 2010

Accepted 24 June 2010

\section{Keywords:}

Soil bacteria

Polymerase chain reaction

Real-time PCR

Denaturing gradient gel electrophoresis

(DGGE)

Long-term fertilization

Manure

\begin{abstract}
A B S T R A C T
Soil bacterial communities mediate a wide range of ecosystem processes. In agricultural systems these processes determine soil health through bacterial roles in residue decomposition, nutrient cycling and their associations with other organisms. In this study, we investigated the abundance and composition of native soil bacterial communities under different long-term fertilization practices using quantitative real-time polymerase chain reaction (qPCR) and denaturing gradient gel electrophoresis (DGGE). Soil samples were taken from a 20-year fertilization trial at the Plastic-film Mulching Experiment Station in Northeast China, which including four treatments of control (CK), inorganic-N fertilizer amendment ( $N$ ), organic manure amendment $(\mathrm{M})$, and half fertilizer-N plus half organic manure $(M+N)$, to identify the difference of soil bacterial community under inorganic fertilizer and manure amendment. The size of the general bacterial population in the $\mathrm{N}$ treatment was significantly smaller than those in the $\mathrm{CK}, \mathrm{M}$ and $\mathrm{M}+\mathrm{N}$ treatments. Soil bacterial 16S rRNA gene copy numbers were positively correlated with soil pH and total organic carbon (TOC) content. The DGGE band patterns in CK, M and M + N treatments demonstrated more similarly to each other than to those of soil with only $\mathrm{N}$ amendment, while canonical correspondence analysis (CCA) revealed that the bacterial community structure in the $\mathrm{N}$ treatment was significantly different from the treatments of $\mathrm{CK}$ and $\mathrm{M}$ bacterial community profiles. Phylogenetic analysis of bands excised from the DGGE gels identified seven major phyla (Acidobacteria, Bacteroidetes, Gemmatimonadetes, Proteobacteria, Actinobacteria, Gammaproteobacteria and Firmicutes) present in all the treatments except the $\mathrm{N}$ treatment, in which no Gammaproteobacteria was observed. Results from this study suggest that agricultural fertilization practices have a great impact on soil bacterial community size and structure.
\end{abstract}

(c) 2010 Elsevier B.V. All rights reserved.

\section{Introduction}

Soil microorganisms have long been recognized for their important role in residue decomposition, nutrient cycling and crop production. Understanding the shifts of microbial community structure and composition following long-term organic and inorganic fertilizer amendments may lead to development of better management practices for agroecosystems (Dolfing et al., 2004). Culture-independent molecular surveys using the $16 \mathrm{~S}$ rDNA, encoding the RNA component of the small subunit of the ribosome, has provided major insights into species and functional diversity of bacterial populations with different soil management practice (Prosser, 2002). Results from such studies have clearly demonstrated perturbation of soil microbial community populations due to changes in environmental conditions and soil management prac-

\footnotetext{
* Corresponding author. Tel.: +86 10 62849788; fax: +86 10 62849788/923563.

E-mail address: jzhe@rcees.ac.cn (J.-Z. He).
}

tices (Smit et al., 2001; Sun et al., 2004). Molecular approaches with soil DNA may answer questions on the long-term effects of fertilizer management on soil bacterial abundance and diversity.

Fertilization has been widely used as a common management practice to maintain soil fertility and crop productivity. The impacts of fertilization on the population, composition and function of soil microorganisms are significant. For example, Hallin et al. (2009) showed different fertilization treatments greatly affected $\mathrm{N}$-cycling communities and ecosystem functioning in a 50-year-old fertilizer field experiment established in 1956 in Sweden. Their results showed that the size of the microbial functional groups were one to two orders of magnitude lower in the sewage sludge and ammonium sulfate treatments compared with the other treatments, which might be explained the lower $\mathrm{pH}$ of 4.0 in these plots. Extensive studies elsewhere have shown similar long-term community shifts (Marschner et al., 2003; Dolfing et al., 2004; Sun et al., 2004; Chu et al., 2007; Ge et al., 2008; He et al., 2008), while still other studies demonstrated that inorganic and organic fertilizers had relatively less effect on soil bacterial diversity and activities when 
investigations were conducted over the short-term (Crecchio et al., 2001; Okano et al., 2004). Additional studies focusing on the microbial community structure dynamics in response to long-term fertilizer management include a 16-year study of a Chinese red soil (He et al., 2007), a 30-year study in the Germany-reclaimed loess soil (Marschner et al., 2003), and a 70-year study of a century-old manure-treated agroecosystem in USA (Sun et al., 2004). Sun et al. (2004) observed a significantly higher number of bacterial ribotypes and more even bacterial distribution in the manure-treated soil as assessed by denaturing gradient gel electrophoresis (DGGE).

Our previous investigations have also studied the community structure of bacteria in Southern Chinese red soil and Northern Chinese alkaline soil under long-term fertilization practices using PCR-DGGE methods (Ge et al., 2008; He et al., 2008). However, little is known about the relationship between bacterial community shift and size change under long-term fertilizer application (Fierer et al., 2005; He et al., 2007; Shen et al., 2008). A 50-year-old fertilization experiment showed the relative importance of size and composition in relation to microbial process involved in nitrogen cycling (Hallin et al., 2009). However, what matters most for ecosystems functioning-composition or size of functional communities still need further studies.

In this study, we collected soil samples from a 20-year fertilization experiment which included nitrogen fertilizer and organic manure amendments to an agricultural soil in Northeast China. Earlier studies at the same site showed that long-term application of inorganic-N fertilizer and organic manure could change the availability of resources to the soil food web and the decomposition pathway (Liang et al., 2009). The aim of this study was therefore to investigate the abundance and community structure of soil bacteria and their association with soil environmental variables using real-time PCR and PCR-DGGE approaches. The relationship between bacterial community size and composition were studied in this study, which showed difference with our previous study on bacteria.

\section{Material and methods}

\subsection{Sampling site}

Soil samples were collected from a Plastic-film Mulching Experiment Station of Shenyang Agriculture University, Liaoning Province, Northeast China $\left(41^{\circ} 49^{\prime} \mathrm{N}, 123^{\circ} 34^{\prime} \mathrm{E}\right)$. This long-term experiment site was established in 1987 with wheat continuous cropping system on loamy brown earth derived from loess-like parent materials. Four replicates of four fertilization treatments were investigated: CK (non-amended), nitrogen (application of urea as $\mathrm{N}$ fertilizer, $135 \mathrm{~kg} \mathrm{Nha}^{-1}$ per year), $\mathrm{M}$ (application of pig compost manure, $135 \mathrm{~kg} \mathrm{~N} \mathrm{ha}^{-1}$ equivalent per year), and $\mathrm{M}+\mathrm{N}$ (combined application of half $\mathrm{N}$ fertilizer and half pig compost manure, $135 \mathrm{~kg} \mathrm{~N}^{-1}$ equivalent per year). Five $20 \mathrm{~cm} \times 5 \mathrm{~cm}$ diameter soil cores mixed as one sample were collected from the upper $20 \mathrm{~cm}$ at the seedling stage of maize in May 2007. The soil samples were sieved to $2.0 \mathrm{~mm}$, and stored at $-80^{\circ} \mathrm{C}$ until DNA extraction. Soil chemical and physical characteristics have been described previously (Liang et al., 2009) and are presented in Table 1.

\subsection{PCR amplification of bacterial 165 rRNA genes}

Nucleic acids were extracted from frozen soils as described previously (He et al., 2007) using an UltraClean ${ }^{\mathrm{TM}}$ soil DNA isolation kit (MoBio, San Diego, CA). Purified DNA was eluted with $50 \mu$ of Solution S5 (MoBio, cat. No 12800-100) and stored at $-20^{\circ} \mathrm{C}$.

Real-time qPCR quantification of bacterial 16S rRNA genes in soil DNA samples was performed on an iCycler iQ5 thermocycler (Bio-
Rad, Hercules, CA) as described previously (He et al., 2007; Shen et al., 2008). The universal primers BACT1369F (5'-CGG TGA ATA CGT TCY CGG-3') and PROK1492R (5'-AAG GAG GTG ATC CRG CCG CA) were used in combination with the probe TM1389F (5'-CTT GTA CAC CGC CCG TC-3'), labeled at the $5^{\prime}$-end with the reporter dye FAM (6-carboxy-fluorescein), and at the $3^{\prime}$-end with the quencher dye TAMRA (6-carboxy-tetramenthylrhodamine), for quantification using iQ Supermix (Bio-Rad). Each reaction was performed in a $25-\mu l$ volume and run using 35 cycles in order to minimize nonspecific background fluorescence. The standard curve for real-time PCR was developed as described previously (He et al., 2007; Shen et al., 2008). Data analysis was carried out with iCycler software (version 1.0.1384.0 CR). The threshold cycle $\left(C_{\mathrm{T}}\right)$ of amplification for each sample was determined as the cycle number at which a statistically significant increase in the reporter fluorescence was detected.

For PCR-DGGE analysis, the primers used for 16S rRNA gene amplification were 954f-GC (5'-[CGC CCG CCG CGC GCG GCG GGC GGG GCG GGG GCA CGG GGG G] GCA CAA GCG GTG GAG CAT GTG G-3') and 1369r (5'-GCC CGG GAA CGT ATT CAC CG-3') (Yu and Morrison, 2004). Amplifications were performed in $25 \mu$ l reaction mixtures containing $1 \times$ PCR buffer, $3.0 \mathrm{mM} \mathrm{MgCl}_{2}, 400 \mu \mathrm{M}$ each dNTP, 2.0 U Taq DNA polymerase (TaKaRa, Otsu, Shiga, Japan), and $500 \mathrm{nM}$ of each primer. The temperature cycling program consisted of an initial denaturation at $94^{\circ} \mathrm{C}$ for $5 \mathrm{~min}$; 10 touchdown cycles of $94{ }^{\circ} \mathrm{C}$ for $30 \mathrm{~s}, 61-0.5^{\circ} \mathrm{C}$ per cycle for $30 \mathrm{~s}$, and $72{ }^{\circ} \mathrm{C}$ for $60 \mathrm{~s} ; 25$ cycles of $94^{\circ} \mathrm{C}$ for $30 \mathrm{~s}, 56^{\circ} \mathrm{C}$ for $30 \mathrm{~s}$, and $72{ }^{\circ} \mathrm{C}$ for $60 \mathrm{~s}$; and a final elongation at $72{ }^{\circ} \mathrm{C}$ for $5 \mathrm{~min}$. PCR products were checked on $1 \%$ agarose gels.

\subsection{DGGE analysis and sequencing}

DGGE analysis of the bacterial 16S rRNA gene products was performed with the DCode Universal Mutation Detection System (Bio-Rad) as described previously (Shen et al., 2008) with slight modifications. Ten microliters of each PCR product (about $25 \mathrm{ng}^{-1} \mathrm{l}^{-1}$ ) were loaded onto $6 \%$ polyacrylamide gradient gels with a denaturing gradient of $40-60 \%$ where $100 \%$ denaturant is defined as $7 \mathrm{M}$ urea and $40 \%$ formamide (Muyzer et al., 1993). Electrophoreses were run at $150 \mathrm{~V}$ for $5 \mathrm{~h}$ at $60^{\circ} \mathrm{C}$. The gels were stained with 1:10,000 SYBR Gold nucleic acid gel stain (Invitrogen 20 Molecular Probes, Eugene, OR) for 30 min according to the manufacturer's instructions, and scanned using a GBOX/HR-E-M (Syngene, UK).

The dominant bands in the DGGE gel with the same mobility were excised and incubated overnight in $10 \mathrm{mM}$ Tris- $\mathrm{HCl}, \mathrm{pH} 8.0$ to elute DNA. Reamplification of the eluted DNA by PCR was carried out as before except that the primers 954f did not possess a GC-clamp at the $5^{\prime}$-end. Purified PCR products were ligated into the pGEM-T Easy Vector (Promega, Madison, WI) according to the manufacturer's instructions. Five positive clones were checked by PCR-DGGE to confirm the mobility, and used for DNA sequencing.

\subsection{Phylogenetic analysis}

The obtained sequences were edited and searched against the NCBI GenBank database using the BLAST. The most similar GenBank sequences to the soil 16S rRNA gene clones (98\% cutoff) were included in phylogenetic analysis. The partial 16S rRNA gene sequences were deposited in the GenBank database under accession nos. EU216572-EU216595 and EU249321.

\subsection{Statistical analysis}

The 16S rRNA gene copy numbers was distributed log-normally and $\log _{10}$-transformed prior to one-way analysis of variance (ANOVA) followed by an S-N-K test, performed using SPSS ver- 
Table 1

The basic chemical characteristics of Shenyang brown soil.

\begin{tabular}{|c|c|c|c|c|c|}
\hline Treatment & $\mathrm{pH}$ & $\mathrm{DOC}^{\mathrm{a}}\left(\mathrm{mg} \mathrm{kg}^{-1}\right)$ & $\mathrm{TOC}^{\mathrm{b}}\left(\mathrm{g} \mathrm{kg}^{-1}\right)$ & $\mathrm{NO}_{3}{ }^{-}\left(\mathrm{mg} \mathrm{kg}^{-1}\right)$ & $\mathrm{NH}_{4}{ }^{+}\left(\mathrm{mg} \mathrm{kg}^{-1}\right)$ \\
\hline CK & 6.34 & 104 & 9.42 & 1.46 & 0.16 \\
\hline $\mathrm{N}$ & 4.90 & 83.4 & 7.85 & 2.71 & 0.44 \\
\hline M & 6.24 & 136 & 10.6 & 0.31 & 0.17 \\
\hline$M+N$ & 5.82 & 104 & 11.2 & 1.96 & 0.41 \\
\hline
\end{tabular}

a Dissolved organic carbon.

b Total organic carbon.

sion 11.5 (SPSS Inc., Chicago, IL). The banding patterns of DGGE gels were analyzed using the software Quantity one 4.5.2 (Bio-Rad). The resulting band profiles were exported and used in statistical analysis as 'species' presence-absence matrices, and all detected bands were evaluated categorically with absence scored as 0 and the presence as 1 . To compare normalized bacterial DGGE patterns and test the influences of soil characteristics on the bacterial community structure, canonical correspondence analyses (CCA) were carried out in Canoco for Windows 4.5 (ter Braak and Šmilauer, 2002). A Monte-Carlo permutation test based on 199 random permutations was used to analysis the relationship between bacterial community and environmental properties. The resulting ordination biplot approximated the weighted average of each species (bands, in this case) with respect to environmental variables, which were represented as arrows. The length of the individual arrow indicated the relative importance of soil characteristics in explaining variation in bacterial profiles. Environmental variables with inflation factor over 20 were not included in the CCA analysis.

\section{Results}

\subsection{Abundance of bacteria in the soil}

The abundance of total bacteria detected with real-time PCR by targeting universal bacterial specific 165 rDNA regions showed significant differences among the four fertilization treatments (Fig. 1). The $16 \mathrm{~S}$ rRNA gene copy numbers in the $N$ treatment at $7.4 \times 10^{9}$ per gram of dry soil was significantly lower than those in other treatments. One-way ANOVA of qPCR results showed that the bacterial $16 \mathrm{~S}$ rRNA gene copy numbers in all the treatments had a significant correlation with soil $\mathrm{pH}(r=0.723, n=16, P<0.01)$ and soil TOC

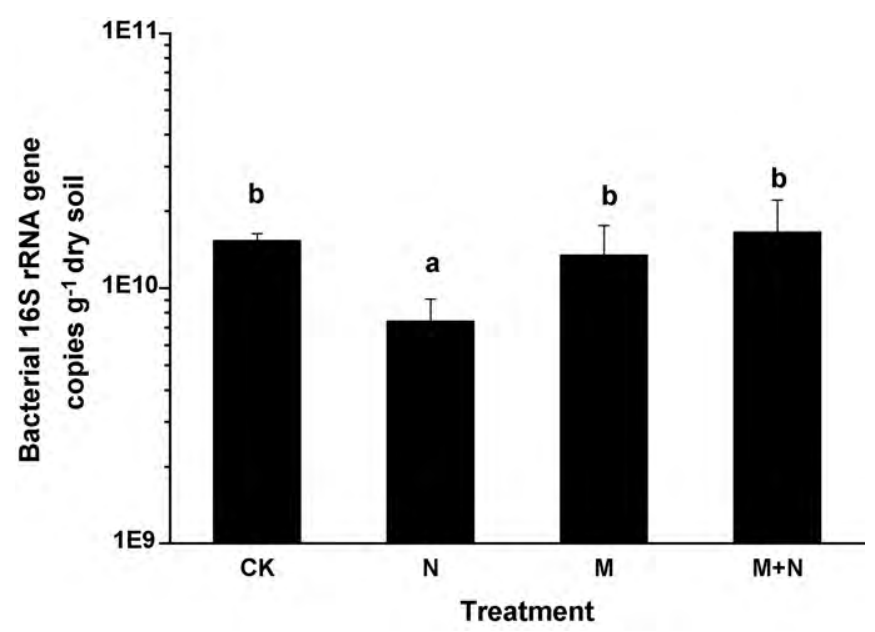

Fig. 1. Abundance of bacterial $16 \mathrm{~S}$ rRNA gene copies under different fertilization treatments. Treatments: control $(C K)$, fertilizer nitrogen $(N)$, manure $(M)$, manure plus half fertilizer nitrogen $(\mathrm{M}+\mathrm{N})$. The different letter on the top of the column showed a statistically significant difference between the treatments at $P=0.05$ level using one-way ANOVA. content $(r=0.557, n=16, P<0.05)$, while no significant correlation with other soil properties (i.e. soil DOC, $\mathrm{NH}_{4}{ }^{+}, \mathrm{NO}_{3}{ }^{-}$).

\subsection{DGGE profiling of bacterial 16S rRNA gene}

The community structure of bacteria was analyzed by PCRDGGE targeting sequence variation present in the 16S rDNA community (Fig. 2). There was a treatment effect and variance within treatments was much lower than variance among treatments based on the DGGE patterns. Twenty-eight dominant DGGE bands in total were detected and numbered (Fig. 2). The DGGE profile of bacteria in the $\mathrm{N}$ treatment was unique relative to the other treatments. For example, bands 17, 22, 24 and 26 were unique to the $\mathrm{N}$ treatment, while bands $4-6,8-10,12,13,21,23,25,27$ and 28 were all detected in other three treatments, i.e. the $\mathrm{CK}, \mathrm{M}$ and $\mathrm{N}+\mathrm{M}$ treatments (Fig. 2 and Table 2). In addition, bands 1-3 appeared with higher intensity in the N treatment DGGE gels than in the other treatment. Although some bands were present in the profiles of all treatments, their intensity varied among treatments. For example, band 10 was strong in the $\mathrm{CK}$ treatment, while slight in the treatments with manure (i.e. treatments $\mathrm{M}$ and $\mathrm{M}+\mathrm{N}$ ) and absent in the $\mathrm{N}$ treatment.

CCA analysis of the DGGE band patterns showed that the $\mathrm{N}$ treatment clustered separately from other treatments, while the $M$ and $\mathrm{M}+\mathrm{N}$ treatments were more closely grouped (Fig. 3 ). It is clear that bacterial community diversity in the manure amendment treatments (Fig. 3) was distributed along the soil carbon gradient, and that the treatments not receiving manure amendment ( $\mathrm{CK}$ and $\mathrm{N}$ ) clustered separately. Based on the partial Monte-Carlo permutation test, our results indicated that both axes explained a highly significant proportion of the variation in the data $(P=0.002)$. The variation within bacterial community structure among the treatments explained $74.6 \%$ and $19 \%$ of the variation on the first two axes (Table 3), respectively. Species-environment correlation coefficients using CCA for the first two axes were more than 0.99 and indicated a significant relationship between bacterial community structure and the selected environmental variables. The first CCA axis was found to be strongly correlated with $\mathrm{pH}, \mathrm{DOC}, \mathrm{TOC}, \mathrm{NO}_{3}{ }^{-}$ and $\mathrm{NH}_{4}{ }^{+}$content, and the second axis was correlated with TOC and $\mathrm{NH}_{4}{ }^{+}$content (Table 3 ), which showed that soil properties under long-term fertilization influenced the bacterial community composition.

\subsection{Phylogenetic analyses}

The BLAST analysis of the 16S rDNA sequences obtained from DGGE gel bands classified the sequences into seven main groups: Acidobacteria, Bacteroidetes, Gemmatimonadetes, Alphaproteobacteria, Actinobacteria, Gammaproteobacteria and Firmicutes (Table 2). All these seven bacterial groups could be detected in all the treatments, except the $\mathrm{N}$ treatment, in which no Gammaproteobacteria were observed (Table 2). Most of the bands in the CK, M and $\mathrm{M}+\mathrm{N}$ treatments had highest similarity database hits to the Acidobacteria ( $20 \%$ of sequenced bands), Sphingobacteria ( $20 \%$ of sequenced bands), and Gemmatimonadetes (20\% of sequenced bands), while 


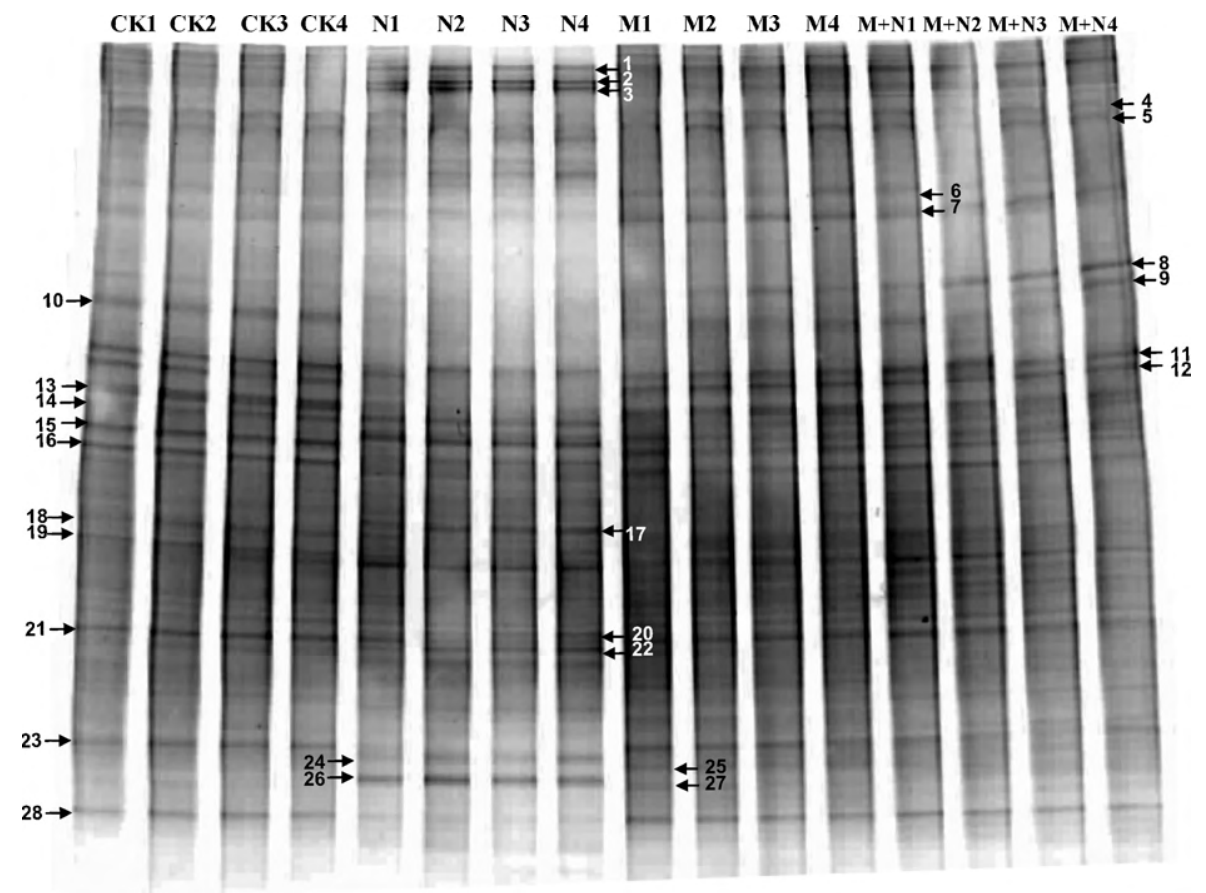

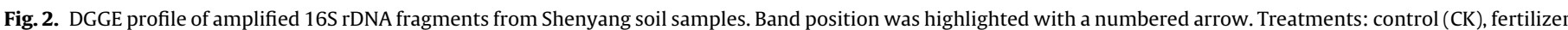
nitrogen $(N)$, manure $(M)$, manure plus half fertilizer nitrogen $(M+N)$.

in the $\mathrm{N}$ treatment the proportion of Acidobacteria were $23 \%$ of sequenced bands. Band 7 fell within the phylum Bacillales and was detected in all treatments.

\section{Discussion}

In this study, culture-independent methods qPCR and PCRDGGE were applied to investigate the abundance and community structure of soil bacteria after 20 years of different fertilizer management regimes. qPCR has recently become a powerful technique for quantitative analysis of bacteria from environmental samples (Suzuki et al., 2000; Fierer et al., 2005). In this study, significant differences in the bacterial 16S rRNA gene copy numbers were obtained between $\mathrm{N}$ treatment and other treatments, which may be explained by the low $\mathrm{pH}, \mathrm{TOC}$ and DOC in the $\mathrm{N}$ treatment (Liang et al., 2009). We observed previously that the abundance of bacteria in $\mathrm{N}$ fertilizer treatment were lower than $\mathrm{CK}$ and NPK + OM treatments in a red Chinese soil (He et al., 2007). Long-term $\mathrm{N}$ fertilizer application could result in a net increase in concentration of protons in the soil, and thus soil acidification. In this experiment, the

Table 2

Tentative identification of dominant DGGE bands in DGGE gels and the closest match to the sequence from GenBank database with BLAST and taxonomic affiliation.

\begin{tabular}{|c|c|c|c|c|c|}
\hline Band number & Accession no. & Origin (treatment) & Closet relative (accession no.) & Alignment, \% similarity & Taxonomic affiliation \\
\hline Band 1 & EU216574 & $\mathrm{CK}, \mathrm{N}, \mathrm{M}, \mathrm{M}+\mathrm{N}$ & Uncultured soil bacterium (GU359109) & 453/457, 99 & Sphingobacteria, Bacteroidetes \\
\hline Band 2 & EU216574 & $\mathrm{CK}, \mathrm{N}, \mathrm{M}, \mathrm{M}+\mathrm{N}$ & Uncultured soil bacterium (GU359110) & $453 / 457,100$ & Sphingobacteria, Bacteroidetes \\
\hline Band 3 & EU216575 & $\mathrm{CK}, \mathrm{N}, \mathrm{M}, \mathrm{M}+\mathrm{N}$ & Bacterium Ellin5032 (AY234449) & 457/459, 99 & Alphaproteobacteria \\
\hline Band 4 & EU216586 & $\mathrm{CK}, \mathrm{M}, \mathrm{M}+\mathrm{N}$ & Uncultured soil bacterium (EF551932) & $447 / 458,97$ & Sphingobacteria, Bacteroidetes \\
\hline Band 5 & EU216587 & $\mathrm{CK}, \mathrm{M}, \mathrm{M}+\mathrm{N}$ & Uncultured bacterium (FJ592639) & 456/457, 99 & Sphingobacteria, Bacteroidetes \\
\hline Band 6 & EU216587 & $\mathrm{CK}, \mathrm{M}, \mathrm{M}+\mathrm{N}$ & Uncultured bacterium (FJ592640) & $456 / 457,100$ & Sphingobacteria, Bacteroidetes \\
\hline Band 7 & EU216588 & $\mathrm{CK}, \mathrm{N}, \mathrm{M}, \mathrm{M}+\mathrm{N}$ & Uncultured bacterium (FJ683738) & 455/456, 99 & Bacillales \\
\hline Band 8 & EU216595 & $\mathrm{CK}, \mathrm{M}, \mathrm{M}+\mathrm{N}$ & Pedobacter sp. BZ42 (GQ161990) & 435/466, 93 & Sphingobacteria, Bacteroidetes \\
\hline Band 9 & EU216575 & $\mathrm{CK}, \mathrm{M}, \mathrm{M}+\mathrm{N}$ & Bacterium Ellin5032 (AY234449) & 457/459, 99 & Alphaproteobacteria \\
\hline Band 10 & EU216589 & $\mathrm{CK}, \mathrm{M}, \mathrm{M}+\mathrm{N}$ & Uncultured gamma proteobacterium (EF142045) & $455 / 455,100$ & Gammaproteobacteria \\
\hline Band 11 & EU216590 & $\mathrm{CK}, \mathrm{N}, \mathrm{M}, \mathrm{M}+\mathrm{N}$ & Uncultured bacterium (FJ479543) & $458 / 458,100$ & Alphaproteobacteria \\
\hline Band 12 & EU216576 & $\mathrm{CK}, \mathrm{M}, \mathrm{M}+\mathrm{N}$ & Uncultured bacterium (FJ525299) & $460 / 462,99$ & Gammaproteobacteria \\
\hline Band 13 & EU216592 & $\mathrm{CK}, \mathrm{M}, \mathrm{M}+\mathrm{N}$ & Uncultured Rhizobiaceae bacterium (FM201296) & 457/459, 99 & Alphaproteobacteria \\
\hline Band 14 & EU216577 & $\mathrm{CK}, \mathrm{N}, \mathrm{M}, \mathrm{M}+\mathrm{N}$ & Uncultured Oxalobacteraceae bacterium (EF019646) & $428 / 465,92$ & Gemmatimonadetes \\
\hline Band 15 & EU216593 & $\mathrm{CK}, \mathrm{N}, \mathrm{M}, \mathrm{M}+\mathrm{N}$ & Uncultured bacterium clone (GQ095375) & $453 / 459,98$ & Acidobacteria \\
\hline Band 16 & EU216573 & $\mathrm{CK}, \mathrm{N}, \mathrm{M}, \mathrm{M}+\mathrm{N}$ & Uncultured bacterium (EU421850) & $458 / 458,100$ & Acidobacteria \\
\hline Band 17 & EU216578 & $\mathrm{N}$ & Uncultured proteobacterium (EF019498) & 453/457, 99 & Acidobacteria \\
\hline Band 18 & EU216578 & $\mathrm{CK}, \mathrm{N}, \mathrm{M}, \mathrm{M}+\mathrm{N}$ & Uncultured proteobacterium (EF019499) & $453 / 457,100$ & Acidobacteria \\
\hline Band 19 & EU216579 & $\mathrm{CK}, \mathrm{N}, \mathrm{M}, \mathrm{M}+\mathrm{N}$ & Uncultured Acidobacteriales bacterium (EU193015) & $454 / 455,99$ & Acidobacteria \\
\hline Band 20 & EU216581 & $\mathrm{CK}, \mathrm{N}, \mathrm{M}, \mathrm{M}+\mathrm{N}$ & Uncultured bacterium (AY917636) & $447 / 452,98$ & Actinobacteria \\
\hline Band 21 & EU216594 & $\mathrm{CK}, \mathrm{M}, \mathrm{M}+\mathrm{N}$ & Uncultured bacterium (GQ402578) & $440 / 458,96$ & Acidobacteria \\
\hline Band 22 & EU216578 & $\mathrm{N}$ & Uncultured proteobacterium (EF019498) & $453 / 457,99$ & Acidobacteria \\
\hline Band 23 & EU216582 & $\mathrm{CK}, \mathrm{M}, \mathrm{M}+\mathrm{N}$ & Uncultured bacterium (EU729911) & $451 / 459,98$ & Gemmatimonadetes \\
\hline Band 24 & EU216580 & $\mathrm{N}$ & Catenulispora acidiphila DSM44928 (СР001700) & $452 / 455,99$ & Actinobacteria \\
\hline Band 25 & EU249321 & $\mathrm{CK}, \mathrm{M}, \mathrm{M}+\mathrm{N}$ & Uncultured bacterium (AB486649) & 455/459, 99 & Gemmatimonadetes \\
\hline Band 26 & EU216572 & $\mathrm{N}$ & Uncultured bacterium (EU239936) & $460 / 460,100$ & Acidobacteria \\
\hline Band 27 & EU216584 & $\mathrm{CK}, \mathrm{M}, \mathrm{M}+\mathrm{N}$ & Uncultured bacterium (GQ069903) & $440 / 464,94$ & Gemmatimonadetes \\
\hline Band 28 & EU216585 & $\mathrm{CK}, \mathrm{M}, \mathrm{M}+\mathrm{N}$ & Uncultured bacterium (EU133743) & $438 / 454,96$ & Sphingobacteria, Bacteroidetes \\
\hline
\end{tabular}




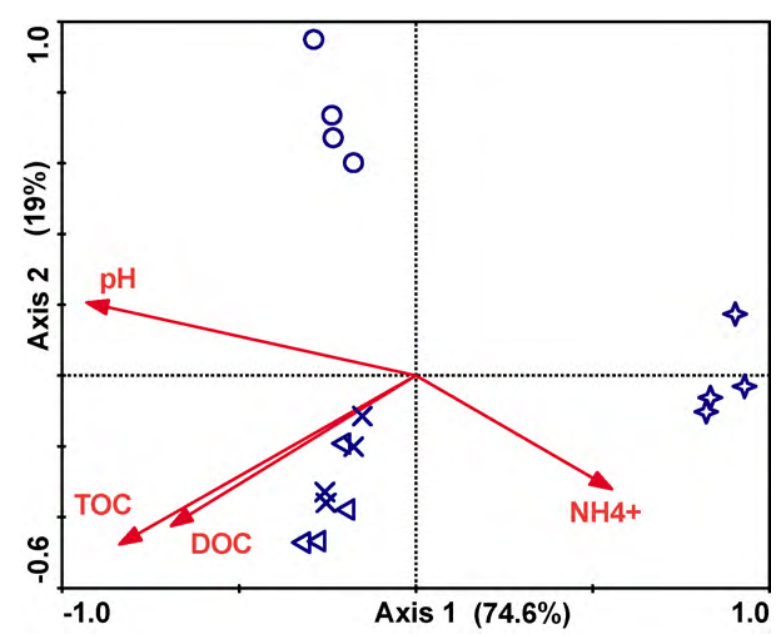

Fig. 3. Canonial correspondence analysis (CCA) ordination diagram of DGGE data, with soil environmental characteristics ( $\mathrm{pH}, \mathrm{DOC}, \mathrm{TOC}, \mathrm{NO}_{3}{ }^{-}$and $\mathrm{NH}_{4}{ }^{+}$) as arrows. Circle symbols represent the $\mathrm{CK}$ treatments, star symbols represent the $\mathrm{N}$ treatments, left-triangle represent the $\mathrm{M}+\mathrm{N}$ treatments, and X-mark symbols represent the $\mathrm{M}$ treatments. Values on the axes indicate \% of total variation explanation by the corresponding axis. DOC: dissolved organic carbon; TOC: total organic carbon.

sampled soil $\mathrm{pH}$ originating from loess-like parent materials was 6.0 before the experiment (Liang et al., 2009), and decreased to pH 4.9 after 20 years of urea-N fertilizer application (Table 1). Significant correlation between bacterial abundance and soil $\mathrm{pH}$ also indicated that soil $\mathrm{pH}$ could have a major effect on the population sizes of bacteria.

The changes in soil pH caused by urea-N fertilization in the $\mathrm{N}$ treatment and its striking influence on bacterial communities has been documented in a number of studies using various molecular methods and traditional approaches (Fierer and Jackson, 2006; Fierer et al., 2007; He et al., 2007). In particular, a recent study by Lauber et al. (2009) showed that soil pH significantly correlated with differences in overall bacterial community composition, and could be used as a predictor of soil bacterial community structure based on the analysis of 88 soils from across North and South America by bar-coded pyrosequencing. Variables that also correlated with the variation in soil bacterial community diversity were soil TOC, DOC, and $\mathrm{NH}_{4}{ }^{+}-\mathrm{N}$.

The DGGE band patterns in $\mathrm{CK}, \mathrm{M}$ and $\mathrm{M}+\mathrm{N}$ treatments judged by the naked eye were clearly more similarly to each other than to those of soils with only $\mathrm{N}$ fertilizer application, which suggested that manure amendment, even in the presence of urea- $\mathrm{N}$ fertilizer application, circumvents the changes in bacterial community structure and abundance observed in the plots treated with urea$\mathrm{N}$ fertilizer. The incorporation of organic manure may provide a conducive environment for microbial proliferation, which could maintain an even distribution of bacterial species with the com-

Table 3

Summary results of the canonical correspondence analysis (CCA).

\begin{tabular}{llcc}
\hline & & Axis 1 & Axis 2 \\
\hline Eigenvalue & & 0.66 & 0.164 \\
$\begin{array}{l}\text { Species-environment correlations } \\
\text { Cumulative percentage variance of } \\
\quad \text { species data }\end{array}$ & 0.993 & 0.981 \\
$\begin{array}{l}\text { Cumulative percentage variance of } \\
\text { species-environment relation }\end{array}$ & 72.9 & 91.0 \\
Weighted correlation & & 75.2 & 93.9 \\
& $\mathrm{pH}$ & -0.919 & 0.295 \\
& $\mathrm{DOC}$ & -0.669 & -0.200 \\
& $\mathrm{TOC}^{-}$ & -0.825 & -0.532 \\
& $\mathrm{NO}_{3}{ }^{-}$ & 0.678 & -0.002 \\
& $\mathrm{NH}_{4}{ }^{-}$ & 0.548 & -0.523 \\
\hline
\end{tabular}

munity (Sun et al., 2004). This result corroborates previous studies showing that bacterial community shifts occurred after long-term application of inorganic-N fertilizer (Dolfing et al., 2004; Sun et al., 2004; Shen et al., 2008), while no such shifts occurred over the short-term (Marschner et al., 2003). Our results are in accordance with other studies showing a decrease in DGGE-identifiable bacterial band under long-term $\mathrm{N}$ fertilizer management regimes (Bruns et al., 1999). However, some studies have demonstrated that the bacterial community structures of $\mathrm{N}$ fertilizer treatments were more similar to the unfertilized treatment (CK) (Chu et al., 2007; Ge et al., 2008). This discrepancy may be explained by the differences in methodologies (such as clone library, sequencing and DGGE), but it is most likely due to the higher soil $\mathrm{pH}$ measured in the above-mentioned studies (Chu et al., 2007; Ge et al., 2008).

A study by Sun et al. (2004) demonstrated using band-sharing coefficients that bacterial communities in manure-treated soil were more closely related to community structure in untreated soil than in soils treated with inorganic-N fertilizers. Interestingly, our results from CCA analysis of relative DGGE band intensity showed that the $\mathrm{M}$ and $\mathrm{M}+\mathrm{N}$ treatments grouped closely together but distinctly from the $\mathrm{CK}$ and $\mathrm{N}$, which grouped separately from each other. CCA has been proven more effective in illustrating the relationship between bacterial community composition and environmental parameters than univariate methods (Salles et al., 2006; Zeng et al., 2009).

Phylogenetic analysis of bacterial 16S rRNA gene suggested that seven major phyla, Acidobacteria, Bacteroidetes, Gemmatimonadetes, Proteobacteria, Actinobacteria, Gammaproteobacteria and Firmicutes were identifiable by PCR-DGGE in this study. These phyla have consistently been detected as the main bacterial divisions in soil environments (Janssen, 2006), such as a century-old manuretreated agroecosystem (Sun et al., 2004), and forest soil under long-term residue management (He et al., 2006). Three of these six divisions, Acidobacteria, Bacteroidetes and Gemmatimonadete, were dominant in this study. The wide distribution and diversity of Acidobacteria has been demonstrated in numerous surveys from environments that vary greatly in physical and biogeochemical characteristics, including soil, marine samples and sediments (Barns et al., 1999; Sun et al., 2004; Janssen, 2006; Kielak et al., 2009). More recently, three genomes from the phylum Acidobacteria revealed putative functions which are important in the environment (Ward et al., 2009). The phylum-level distribution of bands in this study showed that a higher proportion of Acidobacteria were detected in the $\mathrm{N}$ treatment, which lowered the ratio between the Proteobacteria and the Acidobacteria to 0.43 . This ratio might be indicative for the nutrient status in the soil system, as reported ratios at 0.46 in a low-nutrient system (Smit et al., 2001) and 0.87 in a high-input agricultural system (McCaig et al., 1999), while the confirmation of this point will require much more data.

In conclusion, the application of real-time PCR and PCR-DGGE in combination with CCA provides a useful means for detection of differences in soil bacteria communities and abundance. The results of this study clearly demonstrated that the bacteria abundance and community composition were significantly affected by management practice, particularly in soils receiving long-term $\mathrm{N}$ fertilizer application. Microbial communities in soils play a key role in residue decomposition, nutrient cycling and soil symbioses, all of which are good indicators of environmental changes and sustainability of soil ecosystems (Naeem and Li, 1997; Cardinale et al., 2006). The change in soil $\mathrm{pH}$ due to urea- $\mathrm{N}$ fertilizer application was an important factor for bacterial community structure in this study, which is consistent with our previous studies of ammonia oxidizer communities in Chinese acid and alkaline soils receiving variable amendments of $\mathrm{N}$ fertilizer (He et al., 2007; Shen et al., 2008). However, research showed that soil and site characteristics may influence microbial community at local scale (Buckley and 
Schmidt, 2003), while soil $\mathrm{pH}$ is a better predictor at the continental scale (Fierer and Jackson, 2006). Future investigations of environmental factors on microbial diversity in Chinese soils should thus also be conducted on larger scales to address the issue of local versus continental effects.

\section{Acknowledgements}

The soil samples were collected from the long-term fertilization experimental site of Shenyang Agriculture University, China. The authors thank Prof. Jingkuan Wang for technical assistance. This research was financially supported by the Chinese Academy of Sciences (KZCX2-YW-JC401 and KSCX2-YW-G072) and the Natural Science Foundation of China (No. 40901121).

\section{References}

Barns, S.M., Takala, S.L., Kuske, C.R., 1999. Wide distribution and diversity of members of the bacterial kingdom Acidobacterium in the environment. Appl. Environ. Microbiol. 65, 1731-1737.

Bruns, M.A., Stephen, J.R., Kowalchuk, G.A., Prosser, J.I., Paul, E.A., 1999. Comparative diversity of ammonia oxidizer $16 \mathrm{~S}$ rRNA gene aequences in native, tilled, and successional soils. Appl. Environ. Microbiol. 65, 2994-3000.

Buckley, D.H., Schmidt, T.M., 2003. Diversity and dynamics of microbial communities in soils from agro-ecosystems. Environ. Microbiol. 5, 441-452.

Cardinale, B.J., Srivastava, D.S., Duffy, J.E., Wright, J.P., Downing, A.L., Sankaran, M., Jouseau, C., 2006. Effects of biodiversity on the functioning of trophic groups and ecosystems. Nature 443, 989-992.

Crecchio, C., Curci, M., Mininni, R., Ricciuti, P., Ruggiero, P., 2001. Short-term effects of municipal solid waste compost amendments on soil carbon and nitrogen content, some enzyme activities and genetic diversity. Biol. Fertil. Soils 34, 311-318.

Chu, H., Lin, X.G., Fujii, T., Morimoto, S., Yagi, K., Hu, J., Zhang, J., 2007. Soil microbial biomass, dehydrogenase activity, bacterial community structure in response to long-term fertilizer management. Soil Biol. Biochem. 39, 2971-2976.

Dolfing, J., Vos, A., Bloem, J., Ehlert, P.A.I., Naumova, N.B., Kuikman, P.J., 2004. Microbial diversity in archived soils. Science 306, 813-1813.

Fierer, N., Jackson, R.B., 2006. The diversity and biogeography of soil bacterial communities. Proc. Natl. Acad. Sci. U.S.A. 103, 626-631.

Fierer, N., Bradford, M.A., Jackson, R.B., 2007. Toward an ecological classification of soil bacteria. Ecology 88, 1354-1364.

Fierer, N., Jackson, J.A., Vilgalys, R., Jackson, R.B., 2005. Assessment of soil microbial community structure by use of taxon-specific quantitative PCR assays. Appl. Environ. Microbiol. 71, 4117-4120.

Ge, Y., Zhang, J.B., Zhang, L.M., Yang, M., He, J.Z., 2008. Long-term fertilization regimes and diversity of an agricultural affect bacterial community structure soil in northern China. J. Soils Sediments 8, 43-50.

Hallin, S., Jones, C.M., Schloter, M., Philippot, L., 2009. Relationship between Ncycling communities and ecosystem functioning in a 50-year-old fertilization experiment. ISME J. 3, 597-605.

He, J., Shen, J., Zhang, L., Zhu, Y., Zheng, Y., Xu, M., Di, H.J., 2007. Quantitative analyses of the abundance and composition of ammonia-oxidizing bacteria and ammonia-oxidizing archaea of a Chinese upland red soil under long-term fertilization practices. Environ. Microbiol. 9, 2364-2374.

He, J.Z., Xu, Z.H., Hughes, J., 2006. Molecular bacterial diversity of a forest soil under residue management regimes in subtropical Australia. FEMS Microbiol. Ecol. 55, 38-47.
He, J.Z., Zheng, Y., Chen, C.R., He, Y.Q., Zhang, L.M., 2008. Microbial composition and diversity of an upland red soil under long-term fertilization treatments as revealed by culture-dependent and culture-independent approaches. J. Soils Sediments 8, 349-358.

Janssen, P.H., 2006. Identifying the dominant soil bacterial taxa in libraries of $16 \mathrm{~S}$ rRNA and 16S rRNA genes. Appl. Environ. Microbiol. 72, 1719-1728.

Kielak, A., Pijl, A.S., van Veen, J.A., Kowalchuk, G.A., 2009. Phylogenetic diversity of Acidobacteria in a former agricultural soil. ISME J. 3, 378-382.

Lauber, C.L., Hamady, M., Knight, R., Fierer, N., 2009. Pyrosequencing-based assessment of soil $\mathrm{pH}$ as a predictor of soil bacterial community structure at the continental scale. Appl. Environ. Microbiol. 75, 5111-5120.

Liang, W.J., Lou, Y.L., Li, Q., Zhong, S., Zhang, X.K., Wang, J.K., 2009. Nematode faunal response to long-term application of nitrogen fertilizer and organic manure in Northeast China. Soil Biol. Biochem. 41, 883-890.

Marschner, P., Kandeler, E., Marschner, B., 2003. Structure and function of the soi microbial community in a long-term fertilizer experiment. Soil Biol. Biochem. 35, 453-461.

McCaig, A.E., Glover, L.A., Prosser, J.I., 1999. Molecular analysis of bacterial community structure and diversity in unimproved and improved upland grass pastures. Appl. Environ. Microbiol. 65, 1721-1730.

Muyzer, G., Dewaal, E.C., Uitterlinden, A.G., 1993. Profiling of complex microbia populations by denaturing gradient gel electrophoresis analysis of polymerase chain reaction-amplified genes coding for 16S rRNA. Appl. Environ. Microbiol. $59,695-700$.

Naeem, S., Li, S.B., 1997. Biodiversity enhances ecosystem reliability. Nature 390, 507-509.

Okano, Y., Hristova, K.R., Leutenegger, C.M., Jackson, L.E., Denison, R.F., Gebreyesus, B., Lebauer, D., Scow, K.M., 2004. Application of real-time PCR to study effects of ammonium on population size of ammonia-oxidizing bacteria in soil. Appl. Environ. Microbiol. 70, 1008-1016.

Prosser, J.I., 2002. Molecular and functional diversity in soil micro-organisms. Plan Soil 244, 9-17.

Salles, J.F., van Elsas, J.D., van Veen, J.A., 2006. Effect of agricultural management regime on Burkholderia community structure in soil. Microb. Ecol. 52, 267-279.

Shen, J.P., Zhang, L.M., Zhu, Y.G., Zhang, J.B., He, J.Z., 2008. Abundance and composition of ammonia-oxidizing bacteria and ammonia-oxidizing archaea communities of an alkaline sandy loam. Environ. Microbiol. 10, 1601-1611.

Smit, E., Leeflang, P., Gommans, S., van den Broek, J., van Mil, S., Wernars, K., 2001 Diversity and seasonal fluctuations of the dominant members of the bacterial soil community in a wheat field as determined by cultivation and molecular methods. Appl. Environ. Microbiol. 67, 2284-2291.

Sun, H.Y., Deng, S.P., Raun, W.R., 2004. Bacterial community structure and diversity in a century-old manure-treated agroecosystem. Appl. Environ. Microbiol. 70 5868-5874

Suzuki, M.T., Taylor, L.T., DeLong, E.F., 2000. Quantitative analysis of small-subunit rRNA genes in mixed microbial populations via 5'-nuclease assays. Appl. Environ. Microbiol. 66, 4605-4614.

ter Braak, C.J.F., Šmilauer, P., 2002. CANOCO Reference Manual and CanoDraw for Windows User's Guide: Software for Canonical Community Ordination (Version 4.5). Microcomputer Power, Ithaca, NY.

Ward, N.L., Challacombe, J.F., Janssen, P.H., Henrissat, B., Coutinho, P.M., Wu, M., et al., 2009. Three genomes from the phylum acidobacteria provide insight into the lifestyles of these microorganisms in soils. Appl. Environ. Microbiol. 75 2046-2056.

Yu, Z.T., Morrison, M., 2004. Comparisons of different hypervariable regions of rrs genes for use in fingerprinting of microbial communities by PCR-denaturing gradient gel electrophoresis. Appl. Environ. Microbiol. 70, 4800-4806.

Zeng, J., Yang, L.Y., Li, J.Y., Liang, Y., Xiao, L., Jiang, L.J., Zhao, D.Y., 2009. Vertical distribution of bacterial community structure in the sediments of two eutrophic lakes revealed by denaturing gradient gel electrophoresis DGGE and multivariate analysis techniques. World J. Microbiol. Biotechnol. 25, 225-233. 